\title{
The Investigation on the Impact of Financial Crisis on Bursa Malaysia Using Minimal Spanning Tree
}

\author{
Hafizah Bahaludin", Mimi Hafizah Abdullah, ${ }^{1, *}$, Lam Weng Siew ${ }^{2,3}$, Lam Weng Hoe $^{2,3}$ \\ ${ }^{1}$ Department of Computational and Theoretical Sciences, International Islamic University Malaysia, Malaysia \\ ${ }^{2}$ Department of Physical and Mathematical Science, Universiti Tunku Abdul Rahman, Malaysia \\ ${ }^{3}$ Centre for Mathematical Sciences, Universiti Tunku Abdul Rahman, Kampar Campus, Jalan Universiti, Malaysia
}

Received July 11, 2019; Revised September 5, 2019; Accepted September 19, 2019

Copyright $@ 2019$ by authors, all rights reserved. Authors agree that this article remains permanently open access under the terms of the Creative Commons Attribution License 4.0 International License

\begin{abstract}
In recent years, there has been a growing interest in financial network. The financial network helps to visualize the complex relationship between stocks traded in the market. This paper investigates the stock market network in Bursa Malaysia during the 2008 global financial crisis. The financial network is based on the top hundred companies listed on Bursa Malaysia. Minimal spanning tree (MST) is employed to construct the financial network and uses cross-correlation as an input. The impact of the global financial crisis on the companies is evaluated using centrality measurements such as degree, betweenness, closeness and eigenvector centrality . The results indicate that there are some changes on the linkages between securities after the financial crisis, that can have some significant effect in investment decision making.
\end{abstract}

Keywords Financial Network, Minimal Spanning Tree, Centrality Measures

\section{Introduction}

Relationship between two stocks can be measured using a cross-correlation coefficient that uses series of log return as an input. Cross-correlation coefficients play a major role in many areas such as portfolio optimization theory and risk management model. However, if the number of stocks is large, the correlations between stocks cannot be visualised clearly. Thus, building a financial network is necessary so that the interactions between stocks can be displayed clearly. Financial network helps market participants get an overview of the connections between stocks traded in the market.

Minimal spanning tree (MST) is one of the approaches to construct a financial network as suggested by Mantegna [1]. This approach is widely used specifically in analysing the emerging market networks such as the Indian stock market [2], United States stock market [3], Chinese stock market[4], Hong Kong stock market [5],Brazilian stock market [6,7], and Malaysian stock market [8]. Further, researchers are motivated to examine the impact of financial crisis in stock market network. For instance, [9] investigated the structural changes in the minimal spanning tree of the Korean stock market around the global financial crisis. The result showed that there were changes in terms of the topological structure and the central hub of the network for the period before, during and after crisis. [10] showed that the global financial crisis has an impact towards South African stock market in which the network clustered differently in terms of degree centrality, sectorial betweenness centrality and domination strength sub-metric. There are several papers stated that the global financial crisis has different impacts on MST structure such as [3,9,11,12].

Although previous literature applied MST in examining the financial network of various stock markets, to the best of our knowledge, no studies have been found in investigating the impact of global financial crisis on Bursa Malaysia. Thus, this paper aims to examine the effect of a global financial crisis towards Bursa Malaysia by using MST.

This paper is structured as follows. Section 2 presents the data set. Section 3 elaborates the methods to construct the financial network. Section 4 reports the result on how the network changes during pre-, during and post-crises. Section 5 presents the conclusion.

\section{Data}

This paper utilises the adjusted closing price in which adjusted for dividends and split of hundred companies based on top hundreds of market capitalisation listed on 
Bursa Malaysia. The data is obtained from Thomson Reuters Data stream database. The period of the data is from June 2, 2006, to December 30, 2010. The period of the data is divided into three parts; pre-, during and post-crises by referring to the seminal works of Lee and Nobi [9]. This paper considers the period of pre-crisis from June 2, 2006, until November 30, 2007. The duration of crisis period is from December 3, 2007, until June 30, 2009, due to the high mean volatility in all indices[13]. This period is based on the global financial crisis which was started from the bankruptcy of Lehman Brothers [14]. The post-crisis period is from July 1, 2007, until November 30, 2010 , in which the mean volatility of some developed markets return to normal state [9]. The number of stocks for each period varies due to the availability of the data in which pre-crisis has 69 companies, during crisis has 70 companies, and post-crisis has 74 companies. The stocks are divided into twelve sectors: industrial, products and services, energy, property, transportation and logistics, health care, consumer products and services, plantation, financial services, real estate investment trusts, telecommunications and media, utilities, technology and construction. The details of the corresponding symbols, and the sectors of companies are listed in Appendix.

\section{Methodology}

This section presents the procedure to construct a financial network by using minimal spanning tree. The first subsection explains the procedure to construct the network using minimal spanning tree and the second subsection shows the calculation of centrality measures.

\subsection{Minimal Spanning Tree}

L Firstly, cross-correlation matrices based on the log return of adjusted closing prices are calculated. The correlation coefficient, $C_{i j}$, between stocks $i$ and $j$ is given by

$$
C_{i j}=\frac{\left\langle r_{i} r_{j}\right\rangle-\left\langle r_{i}\right\rangle\left\langle r_{j}\right\rangle}{\sqrt{\left(\left\langle r_{i}^{2}\right\rangle-\left\langle r_{i}\right\rangle^{2}\right)-\left(\left\langle r_{j}^{2}\right\rangle-\left\langle r_{j}\right\rangle^{2}\right)}}
$$

where $r_{i}$ is the vector of the log-returns.

The log-returns can be compute as $r_{i}(t)=\ln P_{i}(t+\tau)-\ln P_{i}(t)$ and $P_{i}(t)$ is the price of stock $i$ on date $t$. The symbol $\langle\ldots\rangle$ represents an average over time. Correlation coefficients obtained within the range of $-1 \leq C_{i j} \leq 1$, indicate that -1 means inversely correlated and 1 means completely correlated between stocks. The value of 0 means the stocks are uncorrelated. The correlation coefficient between stocks $i$ and $j$ will form the symmetric $N \times N$ matrix.
Secondly, correlation coefficients are transformed into a distance matrix as suggested by [1] and [15]However, correlation coefficients cannot be considered as a distance between two stocks because they do not satisfy the properties of Euclidean metric which are

$$
\left\{\begin{array}{c}
d_{i j} \geq 0 \\
d_{i j}=d_{j i} \\
d_{i j} \leq d_{i k}+d_{k j}
\end{array}\right.
$$

Thus, the distance between stock $i$ and stock ${ }^{j}$ can be calculated as follows:

$$
D_{i j}=\sqrt{2\left(1-C_{i j}\right)}
$$

Thirdly, financial network is constructed using the minimum spanning tree based on the distance matrix via a Kruskal algorithm[16].There are several steps listed in Kruskal algorithm which are, 1) sort the distance between two stocks in ascending order, 2) choose a pair of stocks with the smallest distance and connect them with an edge, 3 ) choose a second small distance, 4)connect the nearest pair and ignore the pair if it forms a cycle in the network, and 5) repeat the steps until all the stocks are connected in a unique network.

\subsection{Centrality Measures}

Centrality measures are employed for further analyses of the financial network. This study uses four types of centrality measures, namely, degree, betweenness, closeness and eigenvector centrality.

Degree centrality represents the total number of stocks that are connected to a stock $i$. The calculation of degree centrality is as follows:

$$
C_{\text {Degree }}(i)=\frac{\sum_{j}^{N} A_{i j}}{N-1}
$$

where $A_{i j}=1$ if the stock $i$ and stock $j$ is connected and 0 otherwise.

Closeness centrality for one node can be calculated as the average distance of all distances from this node to all other nodes in the network [17] as in equation (5).A stock that has the highest value of closeness centrality is considered important when studying the effect of crisis situation in the network. Further, a stock with a high closeness centrality shows that the overall impact of the connectivity and distance in the network is severe.

$$
C_{\text {closeness }}(i)=\left[\sum_{j=1}^{N} d(i, j)\right]^{-1}
$$

where $d(i, j)$ is the shortest path from stock $i$ and stock $j$.

Betweenness centrality evaluates whether a stock plays a 
role as an intermediate between many stocks. It means that the stock lies between other stocks with respect to their shortest paths. The higher the value of betweenness centrality, the more important is the stock, since it controls the flow of information between many nodes [17]. The betweenness centrality can be evaluated using the following equation (6)

$$
C_{\text {Betweenness }}(i)=\sum_{j<k} \frac{g_{j k}(i)}{g_{j k}} \quad i \neq k \neq j
$$

where $g_{j k}$ is the total number of shortest path from node $j$ to $k$ and $g_{j k}(i)$ is the number of paths that pass through $i$.

The importance of stocks $i$ within the financial network can be measured with eigenvector centrality. The value of this measure relies on a number of other crucial stocks that are linked to stock $i$. Eigenvector centrality is based on an adjacency matrix of the network and can be calculated as in equation (7)

$$
C_{\text {eigen }}(i)=\frac{1}{\lambda} \sum_{j=1}^{N} A_{i j} x_{j}
$$

where $x_{j}$ is the eigenvector of stock $j$ and $A_{i j}$ is an element of the adjacency matrix.

Since each centrality represents different measurements, this paper uses principal component analysis to summarize the performances of stocks in the financial network. The score of stock $i$ based on the overall centrality measure can be evaluated as

$$
U_{i}=e_{1} C_{\text {Degree }}(i)+e_{2} C_{\text {Betweenness }}(i)+e_{3} C_{\text {Closeness }}(i)+e_{4} C_{\text {Eigenvector }}
$$

where $e=\left(e_{1}, e_{2}, e_{3}, e_{4}\right)^{t}$ is the eigenvector of a covariance matrix $\mathrm{S}$ from the vector matrix of size $N \times p$ and $p$ is the first until the fourth column representing the score of degree, betweenness, closeness and eigenvector centrality. This eigenvector is associated with the largest eigenvalue.

\section{Results and Discussion}

Figure 1 shows the pre-crisis minimal spanning tree network of Bursa Malaysia. From the figure, there are three clustered groups in the network, led by Bursa Malaysia Berhad (BMB), Malaysian Resources Corporation (MRC) and DRB-Hicom (DRB). BMB is considered as the centre of the network and is connected with other 14 companies, MRC is connected with other 13 companies, and DRB is connected with other nine companies. In addition, it shows that before the global financial crisis, Malaysian market has a strong reliance on financial services, property, consumer products and service sectors.

However, there are some changes in the network during the crisis period as depicted in Figure 2. BMB and MRC maintained as the centres of the network with additional companies included such as IOI Corporation (IOI) and AMMB Holdings (AMMB). However, DRB was no longer considered as a hub of the network. MST shows that the companies were clustered into four groups during crisis period instead of three groups as before the crisis.

Contrary, after the crisis, the hub of the network disappeared as shown in Figure 3. This changes was similar to the German stock exchange [18] and the Korean stock market [19]. BMB sustained its position as the hub of the network which was connected with 10 companies. Meanwhile, 7 companies were connected to Maybank and MRC, UEM and MPI were connected to 5 companies. The empirical evidence shows that after the global financial crisis, the number of nodes that have links with a hub decreased. 


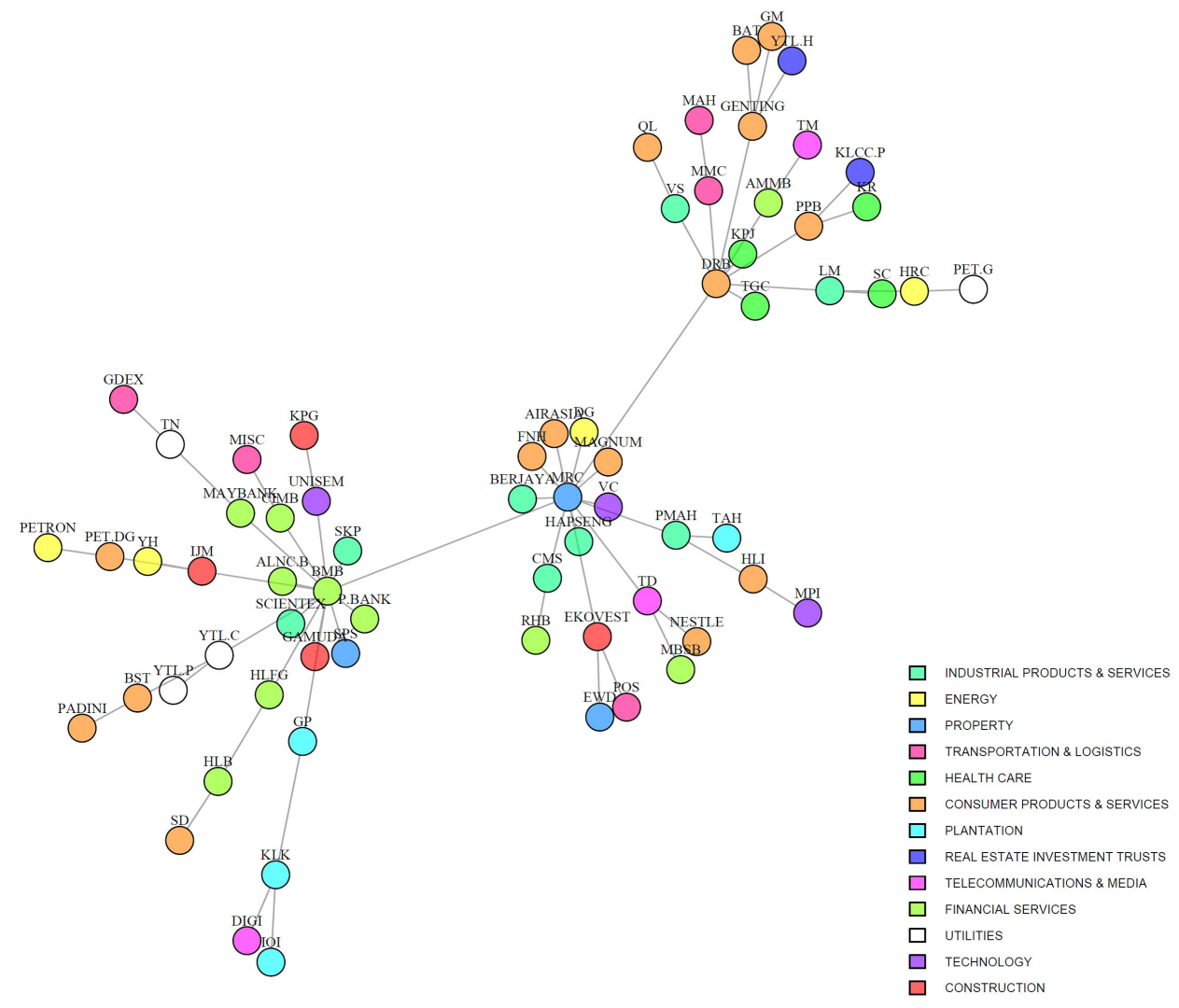

Figure 1. Pre-crisis minimal spanning tree network of Bursa Malaysia (June 2, 2006 - November 30, 2007)

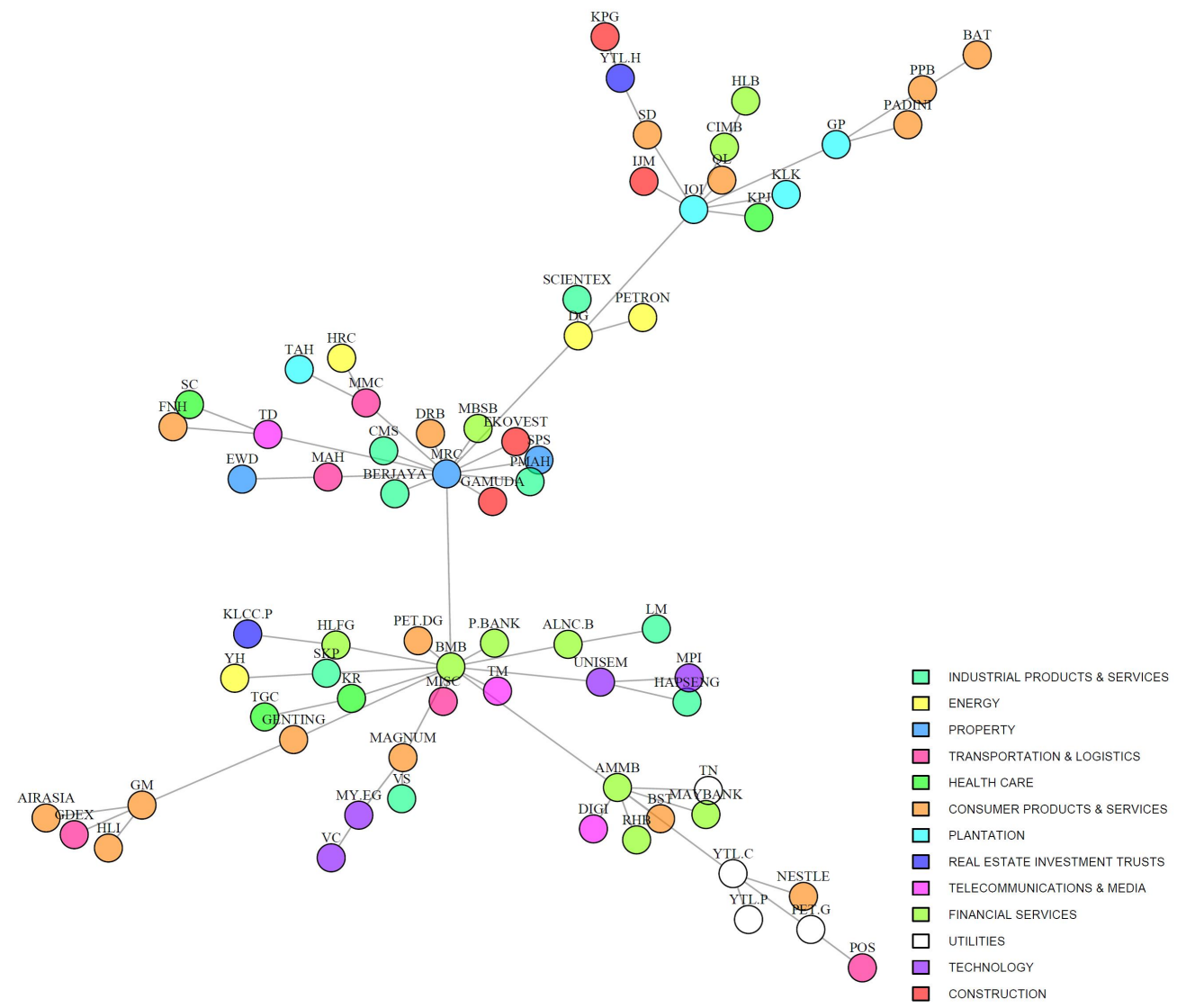

Figure 2. Crisis period minimal spanning tree network of Bursa Malaysia (December 3, 2007 - June 30, 2009) 


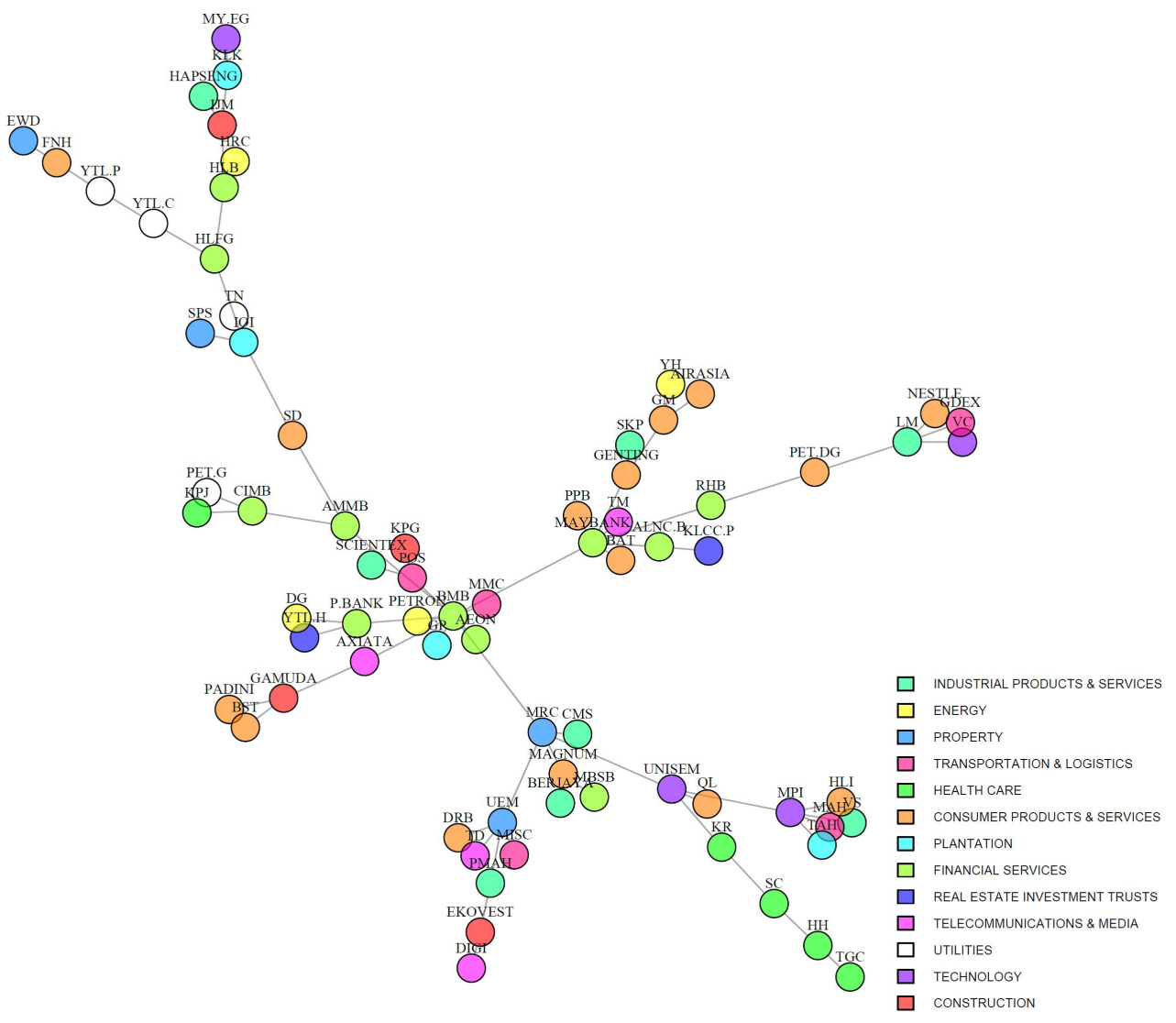

Figure 3. Post-crisis period minimal spanning tree network of Bursa Malaysia (July 1, 2009 - November 30, 2010)

\subsection{Centrality Measure}

Centrality measures are employed for further analyses of the network. There are four types of centrality namely degree, closeness, betweenness and eigenvector. Table 1, Table 2 and Table 3 present the centrality measures for before, during and after the global financial crisis. Before the crisis, BMB, MRC and DRB appeared as top three companies based on degree, betweenness, closeness and eigenvector centrality measures as depicted in Table 1. During the recession or crisis period, BMB and MRC maintained as top scoring companies in terms of all centrality measures as presented in Table 2. Also, AMMB is listed as the top five highest scoring companies in all centrality measures. It shows that AMMB also has a crucial role in the network during recession period. From Table 3, Maybank also can be considered as the most influential company together with BMB and MRC due to the values of betweenness, closeness and eigenvector centrality.

Table 1. Centrality measures during pre-crisis period

\begin{tabular}{|c|c|c|c|c|c|c|c|}
\hline \multicolumn{2}{|c|}{ Degree } & \multicolumn{2}{c|}{ Betweenness } & \multicolumn{2}{c|}{ Closeness } & \multicolumn{2}{c|}{ Eigenvector } \\
\hline BMB & 0.206 & MRC & 0.733 & MRC & 0.409 & BMB & 1.000 \\
\hline MRC & 0.191 & BMB & 0.646 & BMB & 0.386 & MRC & 0.936 \\
\hline DRB & 0.132 & DRB & 0.476 & DRB & 0.348 & DRB & 0.453 \\
\hline GENTING & 0.059 & GENTING & 0.087 & TD & 0.307 & UNISEM & 0.274 \\
\hline TD & 0.044 & LM & 0.086 & EKOVEST & 0.305 & IJM & 0.274 \\
\hline
\end{tabular}

Table 2. Centrality measures during crisis period

\begin{tabular}{|c|c|c|c|c|c|c|c|}
\hline \multicolumn{2}{|c|}{ Degree } & \multicolumn{2}{c|}{ Betweenness } & \multicolumn{2}{c|}{ Closeness } & \multicolumn{2}{c|}{ Eigenvector } \\
\hline BMB & 0.188 & BMB & 0.728 & BMB & 0.385 & BMB & 1.000 \\
\hline MRC & 0.188 & MRC & 0.671 & MRC & 0.381 & MRC & 0.728 \\
\hline IOI & 0.116 & DG & 0.374 & DG & 0.321 & AMMB & 0.386 \\
\hline AMMB & 0.101 & IOI & 0.339 & AMMB & 0.304 & KR & 0.293 \\
\hline YTL.C & 0.058 & AMMB & 0.266 & TD & 0.297 & SKP & 0.291 \\
\hline
\end{tabular}


Table 3. Centrality measures during post-crisis period

\begin{tabular}{|c|c|c|c|c|c|c|c|}
\hline \multicolumn{2}{|c|}{ Degree } & \multicolumn{2}{c|}{ Betweenness } & \multicolumn{2}{c|}{ Closeness } & \multicolumn{2}{c|}{ Eigenvector } \\
\hline BMB & 0.188 & BMB & 0.728 & BMB & 0.267 & BMB & 1.000 \\
\hline MRC & 0.188 & MRC & 0.671 & MRC & 0.239 & MAYBANK & 0.565 \\
\hline IOI & 0.116 & DG & 0.374 & AMMB & 0.233 & MRC & 0.448 \\
\hline AMMB & 0.101 & IOI & 0.339 & MAYBANK & 0.230 & POS & 0.359 \\
\hline YTL.C & 0.058 & AMMB & 0.266 & AXIATA & 0.209 & P.BANK & 0.337 \\
\hline
\end{tabular}

Principal component analysis is used to determine the most influential stock in the network for each period. Before the crisis, the most prominent stocks belong to MRC, BMB and DRB. MRC and BMB are still selected as the companies with the highest scores in overall centrality measures together with AMMB during crisis. After the global financial crisis, MRC, BMB and MAYBANK are the most crucial stocks in Bursa Malaysia.

The dominated stock for each period give the influence in the market in terms of comovement of stock price relatively towards the connected stocks. Besides, the most influential stock has effect on stock returns and the more vital within the network of stock market typically had higher revenue for compensation since they endured greater exposure to correlation risk.

\section{Conclusions}

This paper aims to investigate the effects of global financial crisis on the correlation of stocks traded on Bursa Malaysia using a minimal spanning tree. The Period of data used is divided into three parts: before, during and after the global financial crisis. In general, minimal spanning tree topology changes for each period. Before the crisis, the stocks clustered clearly into three groups and during the crisis, the stocks are dispersed into four groups. However, the stocks are scattered throughout the map after the financial crisis. The results were further assessed using degree, betweeness, closeness and eigenvector centrality. The empirical evidence shows that MRC and BMB are the most crucial stocks before, during and after the crisis.

\section{Acknowledgements}

The authors thank the Ministry of Higher Education Malaysia (MOHE) under Fundamental Research Grant Scheme (FRGS15-191-0432) and International Islamic University Malaysia under Research Initiative Grant Scheme (P-RIGS18-031-0031) for the financial support provided.

\section{Appendix}

Table 4. Companies, sectors and their corresponding symbols

\begin{tabular}{|c|c|c|c|c|c|}
\hline Symbol & Company & Sector & Symbol & Company & Sector \\
\hline VS & VS INDUSTRY & $\begin{array}{c}\text { Industrial Products } \\
\text { \& Services }\end{array}$ & GDEX & GD EXPRESS CARRIER & $\begin{array}{c}\text { Transportation \& } \\
\text { Logistics }\end{array}$ \\
\hline PETRON & $\begin{array}{c}\text { PETRON } \\
\text { MAL.REFN.\& MKTG. }\end{array}$ & Energy & BERJAYA & BERJAYA CORPORATION & $\begin{array}{c}\text { Industrial Products \& } \\
\text { Services }\end{array}$ \\
\hline SPS & SP SETIA & Property & $\mathrm{HH}$ & HARTALEGA HOLDINGS & Health Care \\
\hline SKP & $\begin{array}{c}\text { SKP RESOURCES } \\
\text { BERHAD } \\
\end{array}$ & $\begin{array}{c}\text { Industrial Products } \\
\text { \& Services } \\
\end{array}$ & HLI & HONG LEONG INDUSTRIES & $\begin{array}{c}\text { Consumer Products \& } \\
\text { Services }\end{array}$ \\
\hline MMC & MMC CORPORATION & $\begin{array}{l}\text { Transportation \& } \\
\text { Logistics }\end{array}$ & $\mathrm{TN}$ & TENAGA NASIONAL & Utilities \\
\hline HRC & $\begin{array}{c}\text { HENGYUAN } \\
\text { REFINING COMPANY }\end{array}$ & Energy & SC & SUPERMAX CORPORATION & Health Care \\
\hline KR & KOSSAN RUBBER & Health Care & UNISEM & UNISEM (M) & Technology \\
\hline SD & SIME DARBY & $\begin{array}{c}\text { Consumer Products } \\
\text { \& Services } \\
\end{array}$ & AIRASIA & AIRASIA GROUP & $\begin{array}{c}\text { Consumer Products \& } \\
\text { Services }\end{array}$ \\
\hline PET.DG & $\begin{array}{l}\text { PETRONAS } \\
\text { DAGANGAN }\end{array}$ & $\begin{array}{c}\text { Consumer Products } \\
\text { \& Services }\end{array}$ & PADINI & PADINI HOLDINGS & $\begin{array}{c}\text { Consumer Products \& } \\
\text { Services }\end{array}$ \\
\hline
\end{tabular}




\begin{tabular}{|c|c|c|c|c|c|}
\hline MAGNUM & MAGNUM & $\begin{array}{l}\text { Consumer Products } \\
\text { \& Services }\end{array}$ & KLK & KUALA LUMPUR KEPONG & Plantation \\
\hline CMS & $\begin{array}{l}\text { CAHYA MATA } \\
\text { SARAWAK }\end{array}$ & $\begin{array}{c}\text { Industrial Products } \\
\text { \& Services }\end{array}$ & HAPSENG & HAP SENG CONSOLIDATED & $\begin{array}{c}\text { Industrial Products \& } \\
\text { Services }\end{array}$ \\
\hline IOI & IOI CORPORATION & Plantation & DIGI & DIGI.COM & $\begin{array}{c}\text { Telecommunications } \\
\text { \& Media }\end{array}$ \\
\hline AEON & $\begin{array}{l}\text { AEON CREDIT } \\
\text { SERVICE }\end{array}$ & Financial Services & PET.G & PETRONAS GAS & Utilities \\
\hline GENTING & GENTING & $\begin{array}{l}\text { Consumer Products } \\
\text { \& Services }\end{array}$ & BST & BERJAYA SPORTS TOTO & $\begin{array}{c}\text { Consumer Products \& } \\
\text { Services }\end{array}$ \\
\hline KLCC.P & $\begin{array}{c}\text { KLCC PROPERTY } \\
\text { HOLDINGS STAPLED } \\
\text { UNITS }\end{array}$ & $\begin{array}{l}\text { Real Estate } \\
\text { Investment Trusts }\end{array}$ & MISC & MISC BHD. & $\begin{array}{l}\text { Transportation \& } \\
\text { Logistics }\end{array}$ \\
\hline DRB & DRB-HICOM & $\begin{array}{l}\text { Consumer Products } \\
\text { \& Services }\end{array}$ & CIMB & CIMB GROUP HOLDINGS & Financial Services \\
\hline $\mathrm{TD}$ & TIME DOTCOM & $\begin{array}{c}\text { Telecommunications } \\
\text { \& Media } \\
\end{array}$ & QL & QL RESOURCES & $\begin{array}{c}\text { Consumer Products \& } \\
\text { Services }\end{array}$ \\
\hline LM & $\begin{array}{c}\text { LAFARGE } \\
\text { MALAYSIA }\end{array}$ & $\begin{array}{l}\text { Industrial Products } \\
\text { \& Services }\end{array}$ & KPG & KERJAYA PROSPEK GROUP & Construction \\
\hline PPB & PPB GROUP & $\begin{array}{l}\text { Consumer Products } \\
\text { \& Services }\end{array}$ & ALNC.B & ALLIANCE BANK MALAYSIA & Financial Services \\
\hline MAH & $\begin{array}{c}\text { MALAYSIA } \\
\text { AIRPORTS HDG. }\end{array}$ & $\begin{array}{l}\text { Transportation \& } \\
\text { Logistics }\end{array}$ & TAH & TA ANN HOLDINGS & Plantation \\
\hline TGC & $\begin{array}{c}\text { TOP GLOVE } \\
\text { CORPORATION }\end{array}$ & Health Care & EWD & ECO WORLD DEV.GROUP & Property \\
\hline GP & $\begin{array}{c}\text { GENTING } \\
\text { PLANTATIONS }\end{array}$ & Plantation & GM & GENTING MALAYSIA & $\begin{array}{c}\text { Consumer Products \& } \\
\text { Services }\end{array}$ \\
\hline FNH & $\begin{array}{l}\text { FRASER \& NEAVE } \\
\text { HOLDINGS }\end{array}$ & $\begin{array}{l}\text { Consumer Products } \\
\text { \& Services }\end{array}$ & YTL.H & YTL HOSPITALITY REIT & $\begin{array}{c}\text { Real Estate } \\
\text { Investment Trusts }\end{array}$ \\
\hline MAYBANK & MALAYAN BANKING & Financial Services & POS & POS MALAYSIA & $\begin{array}{l}\text { Transportation \& } \\
\text { Logistics }\end{array}$ \\
\hline NESTLE & NESTLE (MALAYSIA) & $\begin{array}{c}\text { Consumer Products } \\
\text { \& Services }\end{array}$ & BAT & BRIT.AMER.TOB.(MALAYSIA) & $\begin{array}{c}\text { Consumer Products \& } \\
\text { Services }\end{array}$ \\
\hline P.BANK & PUBLIC BANK & Financial Services & HLFG & HONG LEONG FINL.GP. & Financial Services \\
\hline HLB & HONG LEONG BANK & Financial Services & KPJ & KPJ HEALTHCARE & Health Care \\
\hline RHB & RHB BANK BHD & Financial Services & AMMB & AMMB HOLDINGS & Financial Services \\
\hline YTL.C & YTL CORPORATION & Utilities & PMAH & $\begin{array}{c}\text { PRESS METAL ALUMINIUM } \\
\text { HOLDINGS }\end{array}$ & $\begin{array}{c}\text { Industrial Products \& } \\
\text { Services }\end{array}$ \\
\hline YTL.P & $\begin{array}{c}\text { YTL POWER } \\
\text { INTERNATIONAL }\end{array}$ & Utilities & IJM & IJM CORPORATION & Construction \\
\hline MBSB & $\begin{array}{c}\text { MALAYSIA } \\
\text { BUILDING SOC. }\end{array}$ & Financial Services & MPI & MALAYSIAN PACIFIC INDS. & Technology \\
\hline MY.EG & MY EG SERVICES & Technology & DG & DIALOG GROUP & Energy \\
\hline BMB & BURSA MALAYSIA & Financial Services & $\mathrm{TM}$ & TELEKOM MALAYSIA & $\begin{array}{c}\text { Telecommunications } \\
\text { \& Media }\end{array}$ \\
\hline YH & YINSON HOLDINGS & Energy & EKOVEST & EKOVEST & Construction \\
\hline UEM & UEM SUNRISE & Property & SCIENTEX & SCIENTEX & $\begin{array}{c}\text { Industrial Products \& } \\
\text { Services }\end{array}$ \\
\hline VC & $\begin{array}{c}\text { VITROX } \\
\text { CORPORATION } \\
\end{array}$ & Technology & GAMUDA & GAMUDA & Construction \\
\hline MRC & $\begin{array}{l}\text { MALAYSIAN } \\
\text { RESOURCES } \\
\text { CORPORATION }\end{array}$ & Property & AXIATA & AXIATA GROUP & $\begin{array}{l}\text { Telecommunications } \\
\text { \& Media }\end{array}$ \\
\hline
\end{tabular}




\section{REFERENCES}

[1] R. N. Mantegna. Hierarchical structure in financial markets. The European Physical Journal B, Vol.11, No.1, 193-197, 1999.

[2] S. Sinha, R. K. Pan. Uncovering the internal structure of the Indian financial market: large ross-correlation behavior in the NSE. Econophysics of Markets and Business Networks, Vol. 66, 3-19, 2007.

[3] Y. Tang, J. J. Xiong, Z. Jia, Y. Zhang. Complexities in financial network topological dynamics: modeling of emerging and developed stock markets. Complexity, 1-31, 2018.

[4] W-Q. Hunag, X-T. Zhuang, S. Yao. A network analysis of the Chiense stock market. Physica A: Statistical Mechanics and its Applications, Vol.388, No.14, 2956-2964, 2009.

[5] W. Zhang, J. Wen, Y. Zhu. Minimal spanning tree analysis of topological structures: the case of Hang Seng Index. Iberian Journal of Information System and Technologies, Vol.7, 145-155, 2016.

[6] B. M. Tabak, T. R. Serra, D. O. Cajueiro. Topological properties of stock market networks: The case of Brazil. Physica A, Vol.389, 3240-3249, 2010.

[7] L. Sandoval. A map of the Brazilian stock market. Advances in Complex Systems 2, Vol.15, No.4, 2012.

[8] L. S. Yee, R. M. Salleh, N. M. Asrah. Multidimensional minimal spanning tree: The Bursa Malaysia. Journal of Science and Technology, Vol.10, 136-143, 2018.

[9] J. W. Lee, A. Nobi. State and network structures of stock markets around the global financial crisis. Computational Economics. Vol.51, No.2, 195-210, 2017.

[10] M. Majapa, S. J. Gossel. Topology of the South African stock market network across the 2008 financial crisis. Physica A, Vol.445, 35-47, 2016.

[11] E. Kantar, M. Keskin, B. Deviren. Analysis of the effects of the global financial crisis on the Turkish economy, using hierarchical methods. Physica A, Vol.391, 2342-2352, 2012.

[12] L. Xia, D. You, X Jiang, Q. Guo. Comparison between global financial crisis and local stock disaster on top of Chinese stock network. Physica A: Statistical Mechanics and its Applications, Vol.490, 222-230, 2018.

[13] A. Nobi, S. E. Maeng, G. G. Ha, J. W. Lee. Random matrix theory and cross-correlations in global financial indices and local stock market indices. Journal-Korean Physical Society, Vol.62, No.4, 569-574, 2013.

[14] N. Baba, F. Packer. From turnoil to crisis: Dislocations in the FX swap market before and after the failure of Lehman Brothers. Journal of International Money and Finance, Vol.28, No.8, 1350-1374, 2009.

[15] G. Bonanno, G. Caldarelli, F. Lillo, S. Miccich. Networks of equities in financial markets. Physics of Condensed Matter, Vol.38, No.2, 363-371, 2004.

[16] J. Kruskal. On the shortest spanning subtree of a graph and the traveling salesman problem. Proceedings of the American Mathematical Society, Vol.7, No.1, 48-50, 1956.

[17] M. E. J. Newman. A measure of betweenness centrality based on random walks. Social Networks, Vol.27, No.1, 39-54, 2005.

[18] M. Wiliński, A. Sienkiewicz, T. Gubiec, R. Kutner, Z. R. Struzik. Structural and topological phase transitions on the German Stock Exchange. Physica A: Statistical Mechanics and its Applications, Vol.392, 5963-5973, 2013.

[19] A. Nobi, S. E. Maeng, G. G. Ha, J. W. Lee. Structural changes in the minimal spanning tree and the hierarchical network in the Korean stock market around the global financial crisis G. Journal of the Korean Physical Society, Vol.66, No.8, 1153-1159, 2015. 